\title{
短周期成分が卓越した上下方向地震動が 橋梁の地震応答に及ぼす影響
}

\author{
松崎裕 1 ・川島一彦2 \\ 1東京工業大学助教 大学院理工学研究科土木工学専攻 \\ ( ₹152-8552 東京都目黒区大岡山2-12-1) \\ E-mail:matsuzaki.h.aa@m.titech.ac.jp \\ 2東京工業大学教授 大学院理工学研究科土木工学専攻（同上） \\ E-mail:kawashima.k.ae@m.titech.ac.jp
}

\begin{abstract}
近年の強震観測網の充実により, 震源近傍では著しく短周期成分が卓越した上下方向地震動が生起し得 ることが観測事実として明らかとなってきている。本論文は，こうした短周期成分が著しく卓越した上下 方向地震動が一般的な桁橋の地震応答に及ぼす影響について, 2008年岩手・宮城内陸地震の際にKiK-net 一関西観測点で観測された強震記録を用いて, ファイバー解析に基づいて検討した結果を報告するもので ある．本検討は限られた解析条件ではあるが，短周期成分が卓越した上下方向地震動により，橋梁の鉛直 方向の振動特性を支配する固有振動モードが励起されるため, 自重による圧縮軸力の大きさに匹敵する程 の引張軸力が橋脚基部に作用し得ることが明らかとなった.
\end{abstract}

Key Words : vertical ground motion, high frequency components, bridge, seismic performance

\section{1. はじめに}

従来，地震動加速度の上下方向成分は水平方向 成分に比べて小さく，また構造物の地震応答は一 般に水平方向の振動モードが卓越することから, 構造物の耐震設計や地震応答の評価に際して，地 震動の上下方向成分については水平方向成分ほど には関心が持たれてこなかった。道路橋示方書1)を はじめとする我が国の各種耐震基準においても， 耐震安全性の照査時に上下方向成分の影響は, そ れ程, 重要視されてきていない.

一方，近年の強震観測網の充実により，震源の ごく近傍での強震動が次第に観測されるようにな ってきた。2008年に発生した岩手・宮城内陸地震 における KiK-net一関西観測点での強震記録はその 代表例であり, 水平方向成分の最大加速度を大き く上回る, 最大加速度が $4 \mathrm{~g}$ 近い短周期成分が卓越 した上下方向地震動が観測された．震源のごく近 傍, かつ震源が浅い場合には, 従来の震源から中 〜遠距離の強震記録からの知見とは異なり，上下 方向成分が卓越した地震動が生起することが観測 事実として明らかになった。今後, 断層近傍での 観測記録が増えるにつれて，さらに大きな最大加 速度を有する強震記録が得られると考えられる。

こうした上下方向地震動が構造物の地震応答に
及ぼす影響については，菊池ら ${ }^{2)}$, Papazoglou and Elnashai $^{3)}$, Elnashai and Papazoglou ${ }^{4)}$ の研究がある. 菊池らは，弾性解析に基づいて，耐震壁が直上に ない柱に生じる軸力は上下方向地震動の考慮によ り大きく増加することを明らかにしている2). Papazoglou and Elnashai は, 被害地震における被害 の特徴や地震応答解析の結果から，上下方向地震 動の影響を考慮して耐震設計や地震応答解析を行 う必要性を指摘している3). Elnashai and Papazoglou は，上下方向地震動に着目して，その設計用加速 度応答スペクトルを既往の強震記録に基づいて試 算している4).

しかしながら, これらの既往の研究で対象とし ている上下方向地震動の強度は, 水平方向成分の 強度をやや上回る程度のものであり，岩手・宮城 内陸地震のように, 最大加速度が $4 \mathrm{~g}$ に及ぶ強い 上下方向地震動を対象とはしていない。もとより， 最大加速度がいかに大きくとも，構造物の地震応 答にどれだけの影響を及ぼすかが重要であり，そ れを明らかにする必要がある。そこで，本論文で は，こうした上下方向地震動において著しく卓越 した短周期成分が橋梁の地震応答に及ぼす影響に ついて，一般的な桁橋を対象として検討する. 


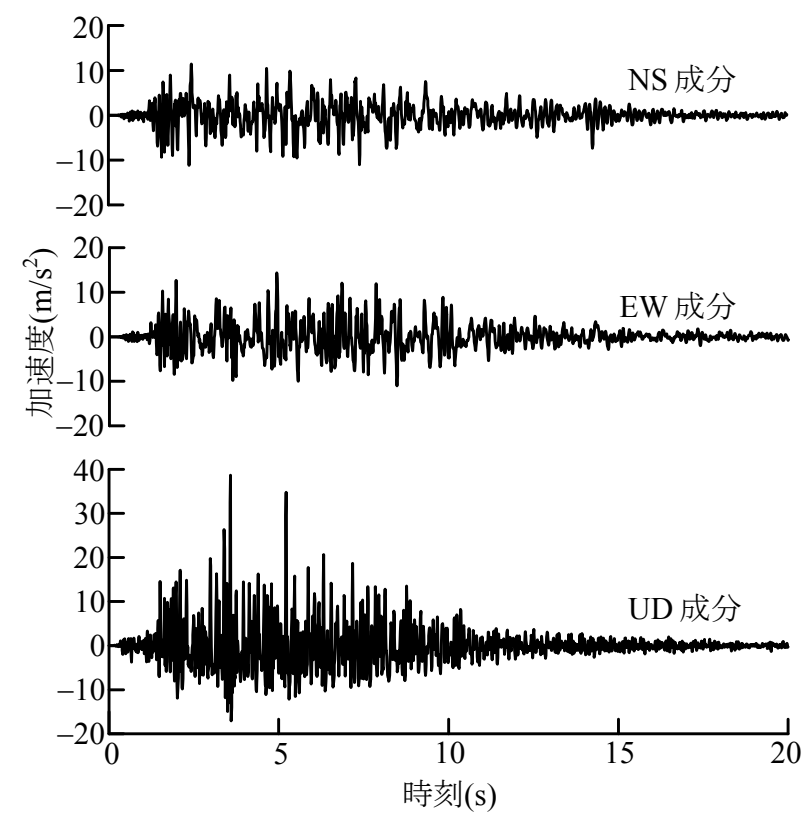

図-1ＫiK-net 一関西の加速度記録

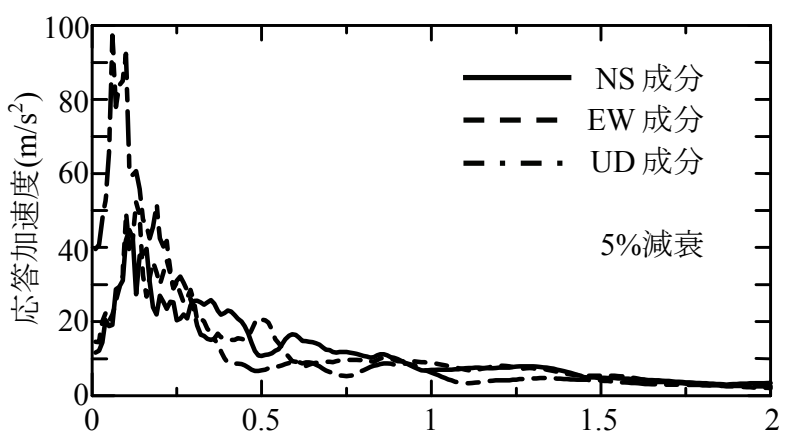

固有周期(s)

図-2 KiK-net一関西記録の加速度応答スペクトル

\section{2. 検討対象とする地震動}

検討対象とするのは，2008年の岩手・宮城内陸 地震の際に, 防災科学技術研究所の基盤強震観測 網KiK-netの一関西観測点において観測された図-1 に示す強震記録である. NS, EW成分の最大加速度 はそれぞれ $11.4 \mathrm{~m} / \mathrm{s}^{2}, 14.3 \mathrm{~m} / \mathrm{s}^{2}$ あ゙ある゙，UD成分の 最大加速度は $38.7 \mathrm{~m} / \mathrm{s}^{2}$ に達している. 加速度応答ス ペクトル（減衰定数 $5 \%$ ) を図-2に示寸が，3成分とも 固有周期 $0.1 \sim 0.3$ 秒前後で卓越しており，特にUD 成分の応答加速度は，0.1秒と短い固有周期におい てではあるが， $92.4 \mathrm{~m} / \mathrm{s}^{2}$ となっている.

前記したように, 本研究では, 上下方向地震動 において卓越した短周期成分が橋梁の地震応答に 及ぼす影響を検討することを目的としている。そ こで，このKiK-net一関西観測点において観測され たオリジナル地震動に加えて, UD成分のうち，水 平 2 成分よりも大きな応答加速度を示している $3 \mathrm{~Hz}$ 以上の振動数成分を以下のローパスフィルター $w(f)$ を用いて除去した地震動も検討対象とする.

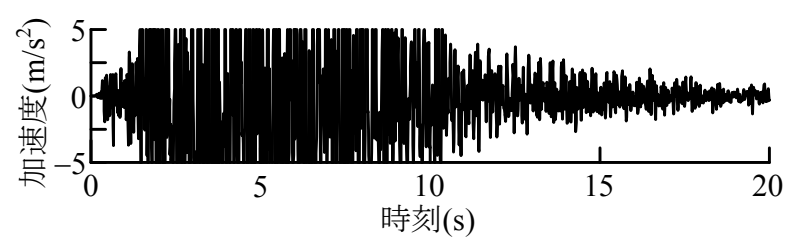

(a) オリジナル地震動

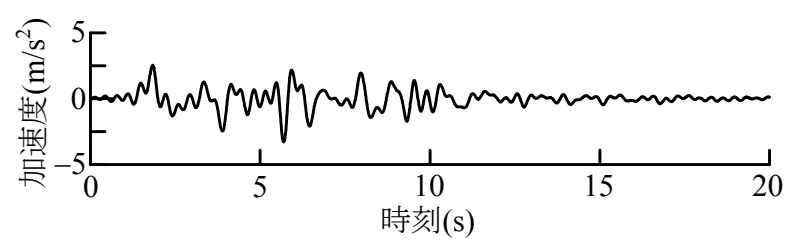

(b) ローパスフィルター処理をした地震動

図-3 3Hz のローパスフィルター処理を行った UD 成分 $(\mathrm{KiK}-\mathrm{net}$ 一関西記録)

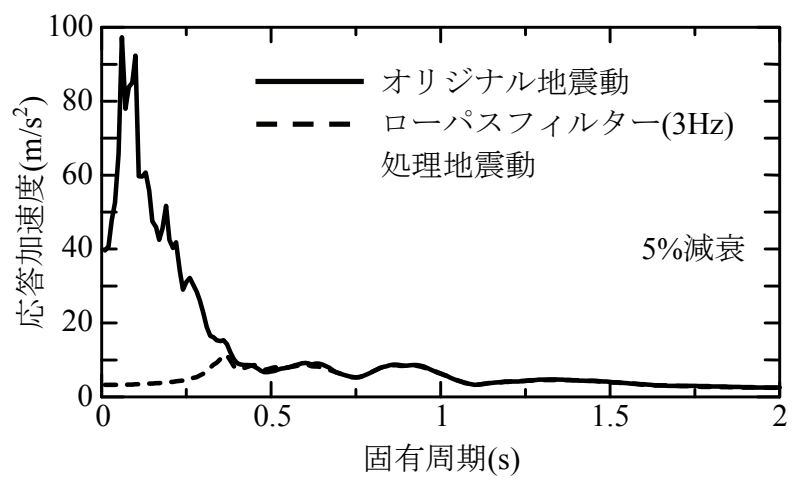

図-4 ローパスフィルター処理前後の KiK-net 一関西記 録 UD 成分の加速度応答スペクトル

$$
w(f)=\left\{\begin{array}{l}
1, f \leq 3 \mathrm{~Hz} \\
0, f>3 \mathrm{~Hz}
\end{array}\right.
$$

なお，後述するように，このローパスフィルタ 一処理を行うことで, 本研究で解析対象とする橋 梁の上下方向の基本固有周期帯域におけるUD成分 は完全に除去されることになる。ローパスフィル ター処理を行った後のUD成分の加速度記録を図-3 に示す. 図-4では，ローパスフィルター処理を行う 前後のUD成分の加速度応答スペクトルを比較して いるが，3Hz以上の振動数成分を除去したことによ り, 対応する振動数域での応答加速度が大きく低 下している。

また，KiK-net一関西記録ほどには短周期領域で の上下方向成分が強くはないが，従来，観測され た中の代表的な強震記録として，1995年の兵庫県 南部地震の際にJR鷹取駅で観測された強震記録も 比較対象として用いる. 図-5にその加速度記録を, 図-6に加速度応答スペクトル（減衰定数 $5 \%$ )を示す.

\section{3. 解析対象橋梁とそのモデル化}

解析対象とするのは, 図-7 に示寸弾性積層ゴム 支承で支持された 5 径間連続鋼桁橋である ${ }^{5)}$. 解析 


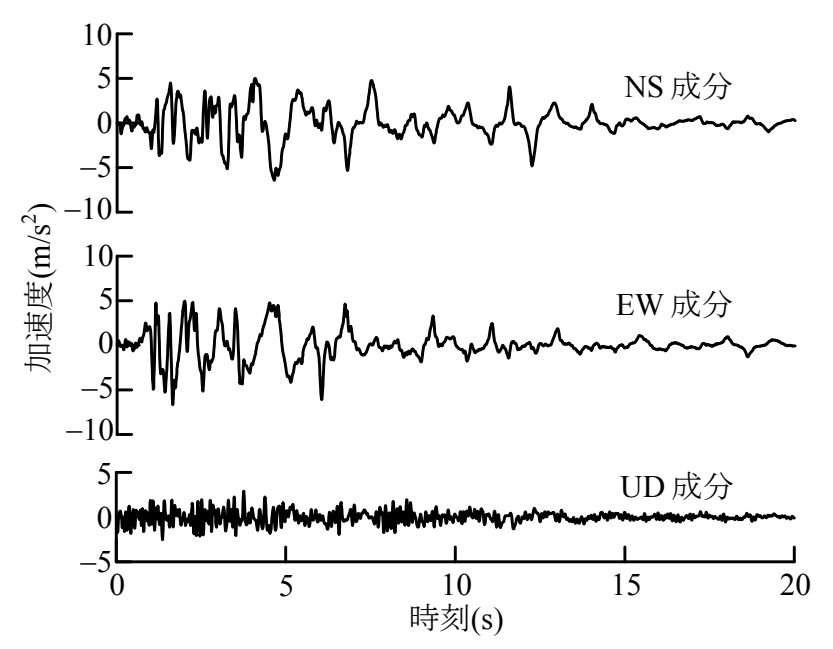

図-5 兵庫県南部地震 JR 鷹取駅の加速度記録

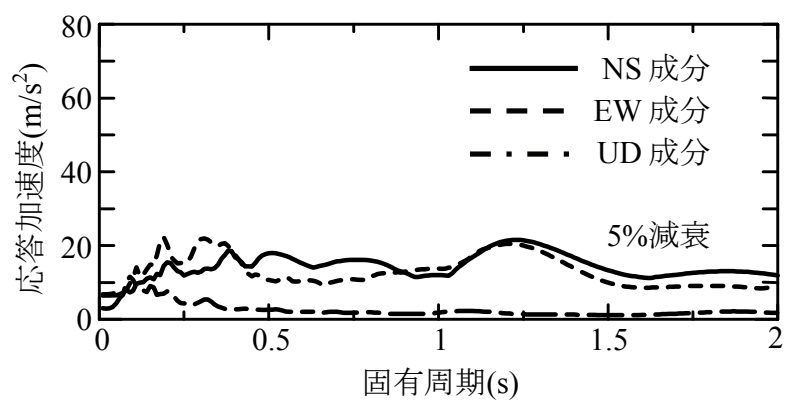

図-6 JR 鷹取駅記録の加速度応答スペクトル

においては，橋脚基部の塑性ヒンジ部はファイバ 一要素, 支承及び地盤ばねは線形ばね要素，その 他の部材は線形はり要素によってモデル化した。 塑性ヒンジ部におけるコンクリートの応力ーひず み履歴については, 包絡線は Hoshikuma et al.によ る提案モデル ${ }^{6}$ を, 除荷・再載荷履歴には Sakai and Kawashima によるモデル ${ }^{7)}$ を用いた。また，鉄 筋の応力ーひずみ履歴には堺・川島による修正 Menegotto-Pinto モデル ${ }^{8)}$ を用い，ひずみ硬化の影響 を取り込むために, 鉄筋の降伏後の剛性は初期弾 性係数の $2 \%$ と仮定した. コンクリート圧縮強度は $20.6 \mathrm{MPa}$ ，鉄筋の降伏強度は $295 \mathrm{MPa}$ としている。 積層ゴム支承の剛性は表-1 の通りとした。積層ゴ ム支承の圧縮側と引張側の剛性の違いや破断の影 響は考慮しないが，これは，本解析の目的が積層 ゴム支承の特性を検討することではなく，橋脚の 応答を検討することにあるためである.

固有值解析の結果, 橋脚の塑性ヒンジ部が弾性 範囲にある場合には，橋梁全体系の基本固有周期 は橋軸方向には 1.17 秒，橋軸直角方向には 1.00 秒, 上下方向には 0.23 秒となる. 橋軸及び橋軸直角方 向については, いずれも積層ゴム支承の変形が卓 越する振動モードである. 図-8 は，橋軸方向の基 本周期に対応する 1 次モード(1.17秒) と, 橋軸直角 方向の基本周期に対応する 2 次モード (1.00秒), 上 下方向の振動が卓越する 9 次モード (0.23 秒)を示し たものである。前記したように, 本研究では, KiK-net 一関西記録の UD 成分について, $3 \mathrm{~Hz}$ のロ

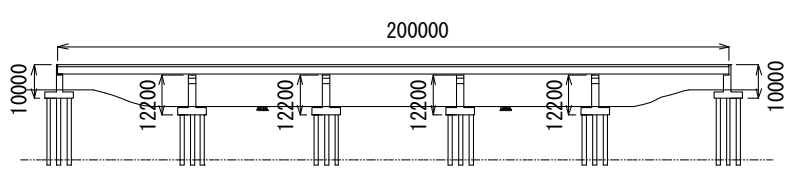

(a) 側面

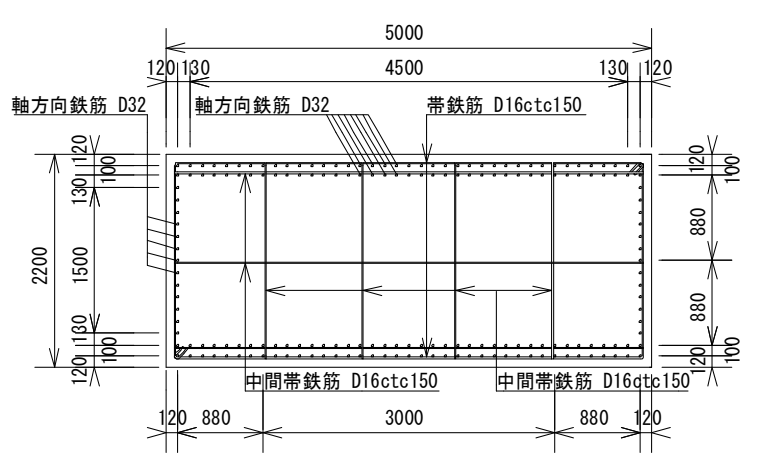

(b) 橋脚断面

図-7 解析対象橋梁

表-1 下部構造1基当たりの支承のばね定数

\begin{tabular}{c|c|c}
\hline & 橋台上の支承 & 橋脚上の支承 \\
\hline \hline 橋軸方向 & $8.19 \times 10^{3} \mathrm{kN} / \mathrm{m}$ & $2.36 \times 10^{4} \mathrm{kN} / \mathrm{m}$ \\
\hline 橋軸直角方向 & 固定 & $2.36 \times 10^{4} \mathrm{kN} / \mathrm{m}$ \\
\hline 鋁直方向 & $2.73 \times 10^{6} \mathrm{kN} / \mathrm{m}$ & $7.86 \times 10^{6} \mathrm{kN} / \mathrm{m}$ \\
\hline
\end{tabular}

一パスフィルター処理を行った地震動も考慮する が，ローパスフィルター処理を行うことにより， こうした橋梁の上下方向の振動モードに対応する 短周期成分が除去されていることになる.

動的解析に際して, 減衰は Rayleigh 減衰により 与えた。各構造要素の減衰定数としては，ゴム支 承には $1 \%$ ，桁及び橋脚躯体には $2 \%$ ，基礎には 20\%を与え，ひずみエネルギー比例減衰法によって 算定されるモード減衰定数を基に, 1 次と 6 次の振 動モードを基準モードとして Rayleigh 減衰のパラ メータを定めた。また， Newmark の $\beta$ 法 $(\beta=1 / 4)$ に よる直接積分法を用い, 積分時間間隔は 0.001 秒と した。 KiK-net 一関西記録では, $0.1 \mathrm{~Hz}$ 前後に卓越 振動数帯があるが，この積分時間間隔であれば, 解析結果に影響がないことを確認している。

以上の橋梁に対して, KiK-net一関西記録及びJR 鷹取駅記録のいずれについても，EW成分及びNS成 分をそれぞれ橋軸方向及び橋軸直角方向に，UD成 分を上下方向に入力した.

\section{4. 上下方向地震動が橋梁の地震応答に及ぼ す影響}

KiK-net 一関西記録及び JR 鷹取駅記録を入力し た場合の P1 橋脚上の桁に生じる応答加速度と変位 を図-9～図-12 に示す．なお，上下方向の応答変位 の初期值が-4mm となっているが，これは自重を作 


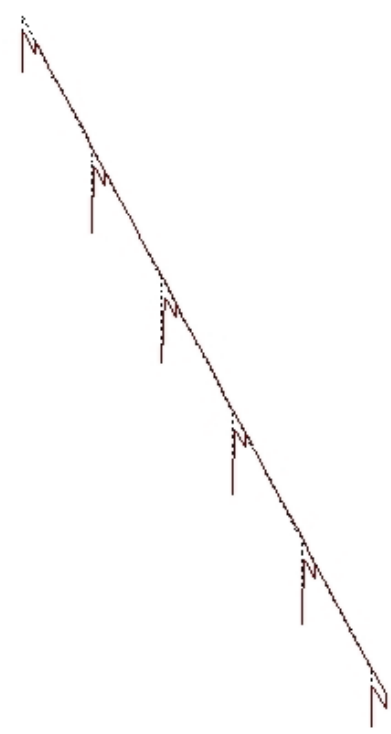

(a) 1 次モード(1.17秒)

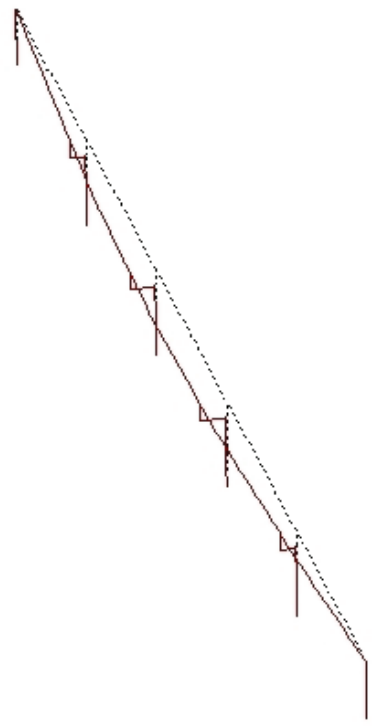

(b) 2 次モード(1.00 秒)

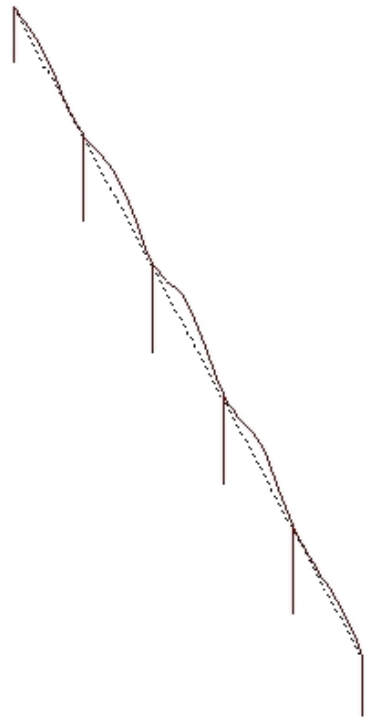

(c) 9 次モード(0.23 秒)

図-8 固有振動モード

一オリジナル地震動

- - - ローパスフィルター $(3 \mathrm{~Hz})$ 処理地震動

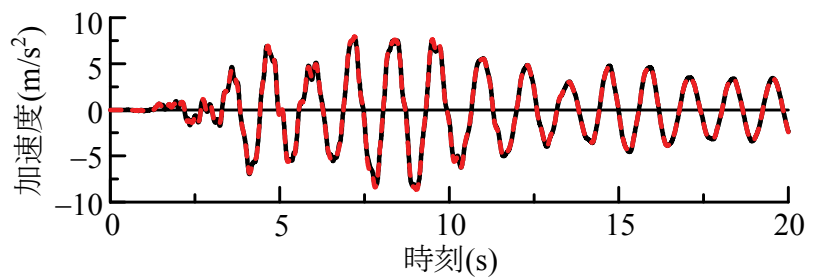

(a) 橋軸方向

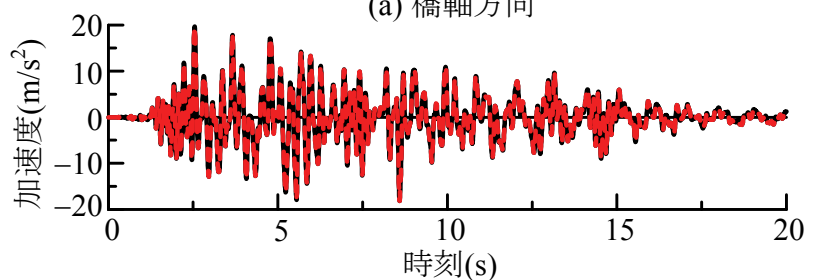

(b) 橋軸直角方向

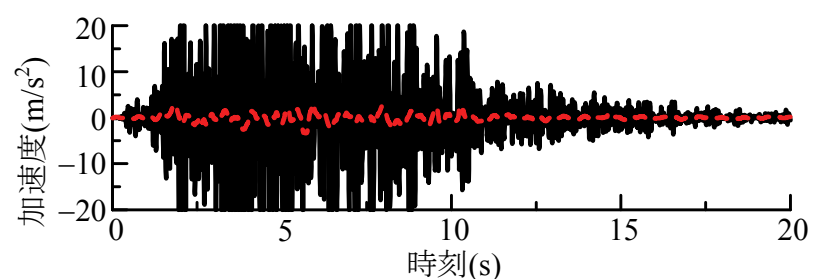

(c) 鉛直方向
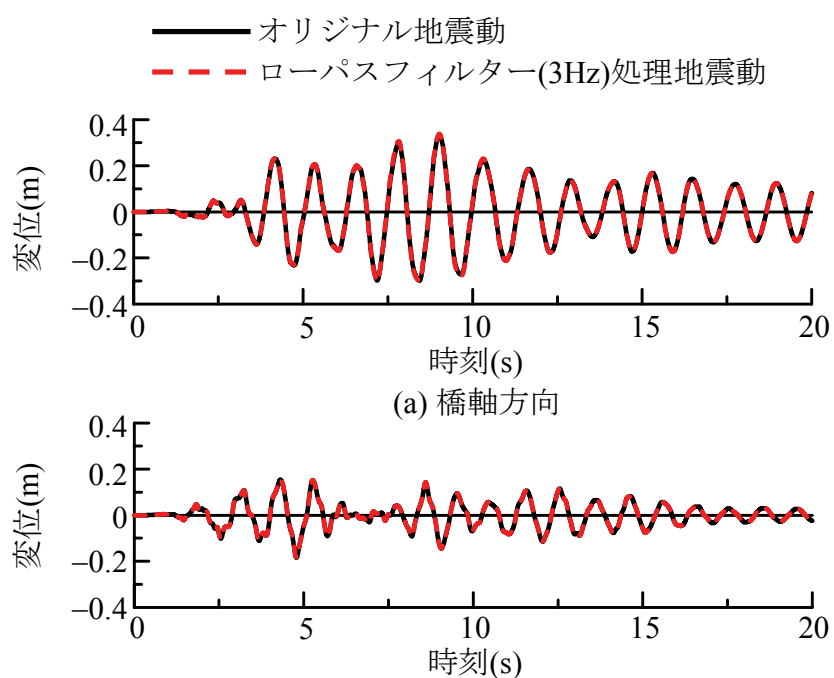

(b) 橋軸直角方向

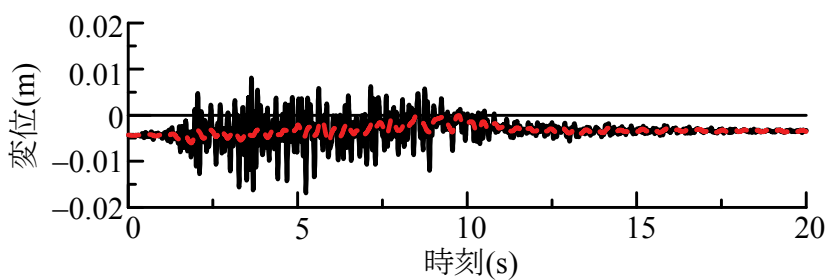

(c) 鉛直方向

用させる前の状態からの変位を示しているためで ある。橋軸方向の最大応答変位に着目すると, KiK-net 一関西記録のオリジナル地震動を入力した 場合には $333 \mathrm{~mm}$, ローパスフィルター処理を行っ た地震動を入力した場合には $337 \mathrm{~mm}$ とほとんど相 違はない. なお，KiK-net一関西記録のオリジナル 地震動を入力した場合であっても，図-4 及び図-6 から明らかなように，橋梁の水平方向の振動モー

図-10 KiK-net一関西記録に対する P1 橋脚上の桁の変位

ドに対応する周期帯では，JR 鷹取駅記録に比べて 応答加速度が小さいことから，上述した橋軸方向 の桁の最大応答変位は $333 \mathrm{~mm}$ と JR 鷹取駅記録を 入力した場合 $(635 \mathrm{~mm})$ の半分程度となっている。一 方で，上下方向の応答変位については，上下方向 成分にローパスフィルター処理をした地震動を入 力した場合には $6.0 \mathrm{~mm}$ と，オリジナル地震動を入 力した場合の $16.9 \mathrm{~mm}$ に比べて小さくなっている. 


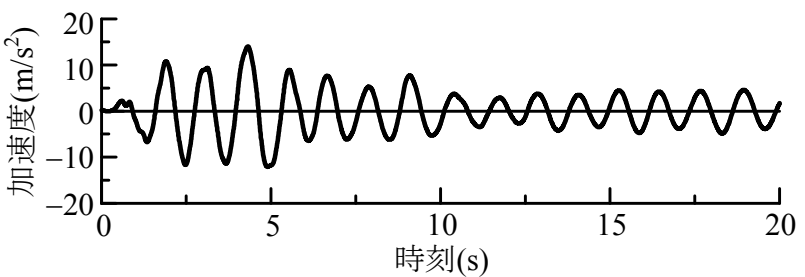

(a) 橋軸方向

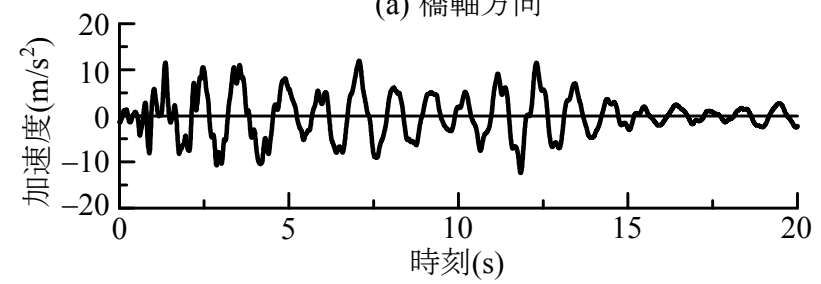

(b) 橋軸直角方向

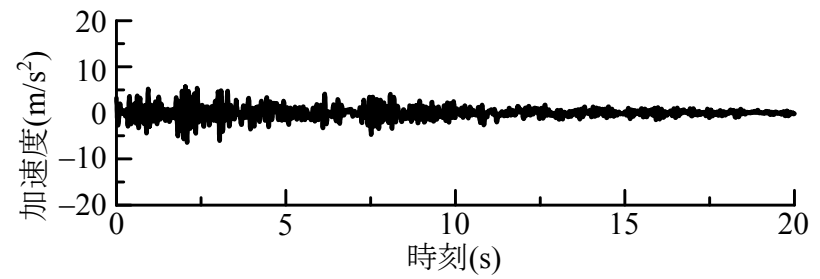

図-11 JR 鷹取駅記録に対する P1 橋脚上の桁の加速度

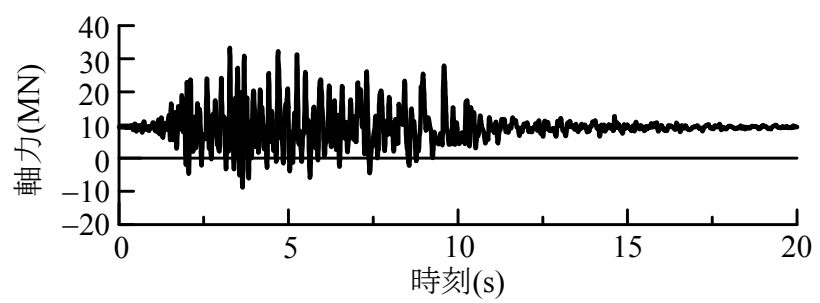

(a) オリジナル地震動

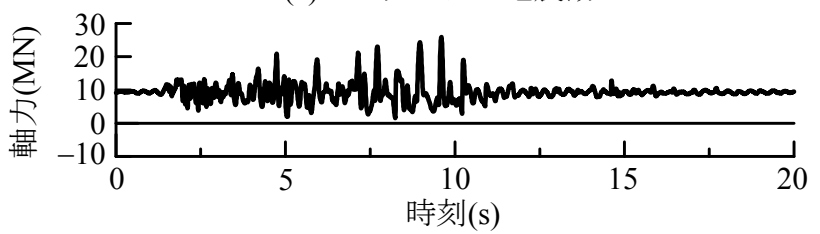

(b) ローパスフィルター $(3 \mathrm{~Hz})$ 処理地震動

図-13 KiK-net 一関西記録に対する P1 橋脚基部の軸力

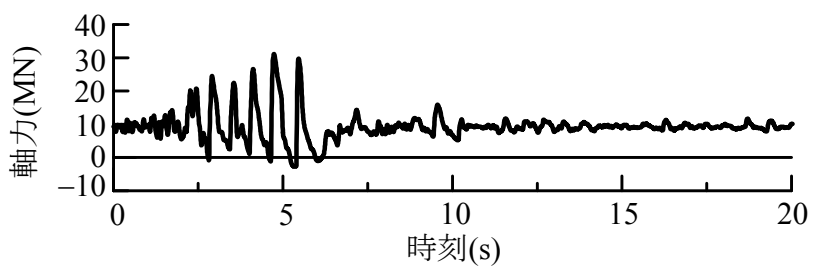

図-14 JR 鷹取駅記録に対する P1 橋脚基部の軸力

次に，橋脚基部に作用する軸力を，P1 橋脚を例 に示すと，図-13 及び図-14 のようになる．図-13(a) に示されているように, KiK-net 一関西記録のオリ ジナル地震動を入力した場合には，圧縮軸力のみ ならず, $8.88 \mathrm{MN}$ もの引張軸力が生じる.これは自 重による圧縮軸力 $9.30 \mathrm{MN}$ に匹敵する.

続いて，P1 橋脚基部の塑性ヒンジ区間における

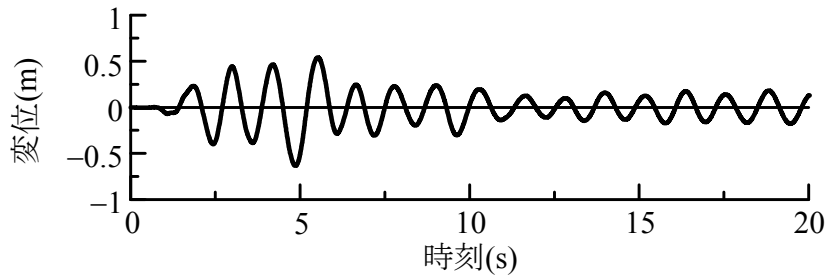

(a) 橋軸方向

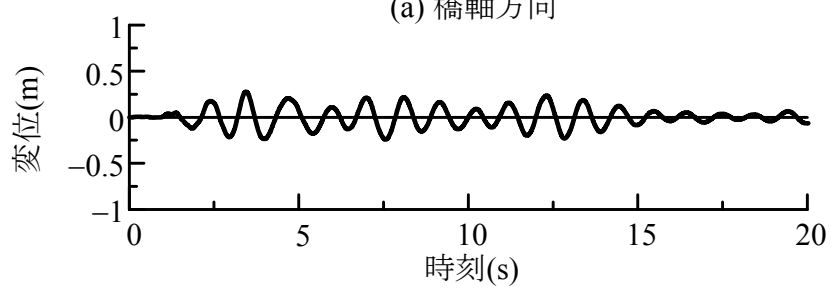

(b) 橋軸直角方向

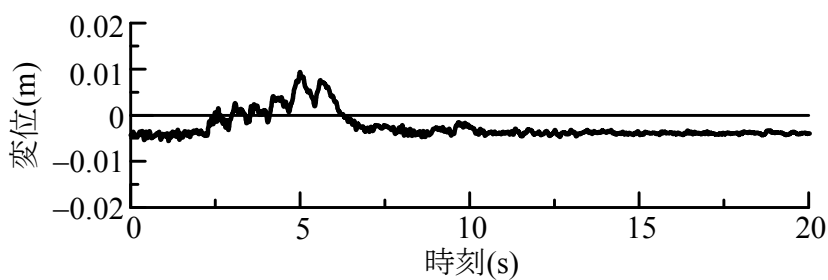

(c) 鉛直方向

図-12 JR 鷹取駅記録に対する P1 橋脚上の桁の変位

橋軸方向の曲げモーメントー曲率の履歴について, KiK-net 一関西記録及び JR 鷹取駅記録を作用させ た場合のそれぞれについて，図-15 及び図-16 に示 す. KiK-net 一関西記録のオリジナル地震動を入力 した場合には，前記したように，上下方向の振動 モードに対応した軸力変動のために，曲げ耐力が 変化する影響が曲げモーメントー曲率の履歴に表 れている，ただし，図-10 及び図-12 に示した桁の 応答変位からも推定されるように, 最大曲率は, $\mathrm{JR}$ 鷹取駅記録を入力した場合の $0.023 \mathrm{l} / \mathrm{m}$ に対して, KiK-net 一関西記録のオリジナル地震動を作用させ た場合には $0.00451 / \mathrm{m}$ に留まっており, 橋脚に与 える塑性曲率という観点では KiK-net 一関西記録の 影響が大きい訳ではない.

なお，こうした引張軸力を含む程の大きな軸力 変動がRC部材の曲げ耐力に及ぼす影響に関しては, 建築分野では, 小野ら ${ }^{9)}, \mathrm{Abrams}^{10)}$ の研究等, 多く 研究されてきている。しかし，これらは建築構造 物の柱を対象としていることから， RC橋脚に比べ てせん断スパン比が小さく，また大きな軸力を受 ける場合のものであり，橋脚に適用できるもので はない.

一方，土木分野で橋脚を対象とした検討として は，堺・川島の研究 ${ }^{11}$ がある。堺・川島は， $1 \mathrm{MPa}$ の引張軸力から $2.7 \mathrm{MPa}$ までの圧縮軸力の範囲での 軸力変動を考慮した静的繰返し載荷実験及びファ イバー解析による検討を行っている。その結果に よれば，自重による圧縮応力と同レベルの $1 \mathrm{MPa} の$ 引張応力に相当する変動軸力作用下であっても, 曲げ耐力は減少はするが安定した履歴を示すこと が明らかにされている。また，引張軸力を生じる 
— オリジナル地震動

- - - ローパスフィルター $(3 \mathrm{~Hz})$ 処理地震動

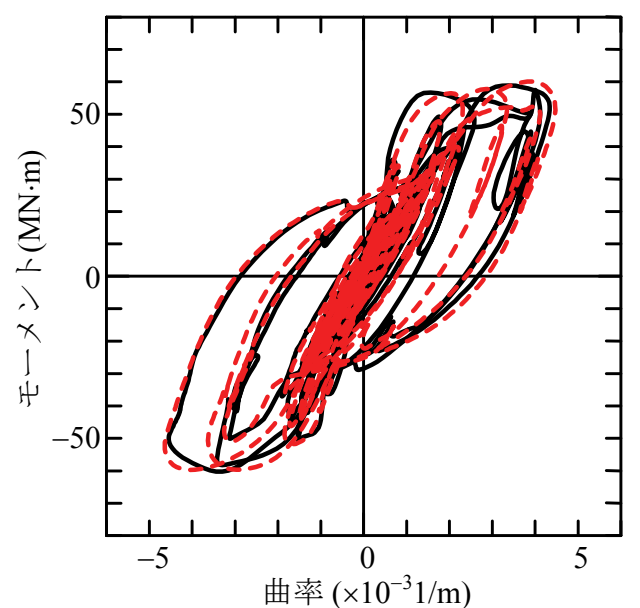

図-15 KiK-net一関西記録に対する P1 橋脚基部のモーメ ントー曲率の履歴 (橋軸方向)

— オリジナル地震動

- - ー ローパスフィルター $(3 \mathrm{~Hz})$ 処理地震動

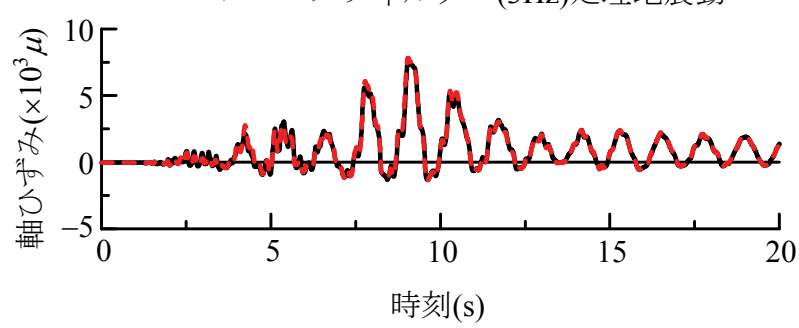

図-17 P1 橋脚の軸方向鉄筋ひずみの時刻歴

(KiK-net一関西記録，橋軸方向最外縁軸方向鉄筋位置）

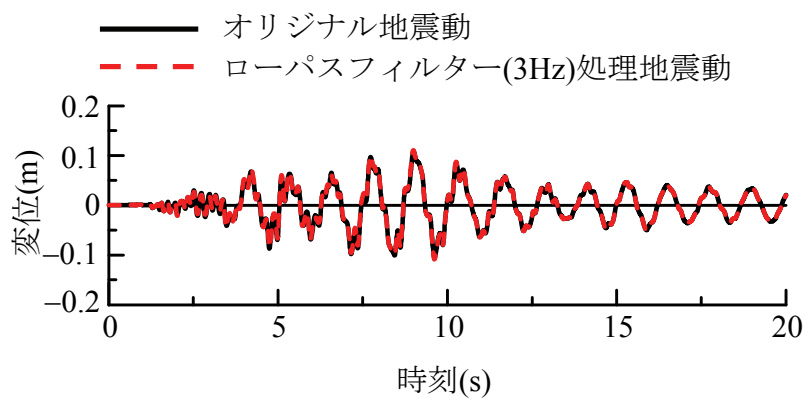

図-19 P1 橋脚上端の変位

(KiK-net 一関西記録，橋軸方向）

ような変動軸力作用下でも，ファイバー解析によ り, 通常の圧縮力作用下と同等の精度で曲げ復元 力特性を評価できていることが示されている。し かしながら，堺・川島の研究においては，軸力の 変動と曲げの変動を連動させており, KiK-net一関 西記録が作用した場合のように，軸力と曲げが異 なった周期特性で作用する場合の検討は行われて いない。

以上のように，引張軸力を含む軸力変動が橋梁 の耐震性に及ぼす影響については，震源近傍での 橋梁の耐震性を考える上で明らかにすべき項目で あり, 今後, 実験と解析の両観点からさらなる検

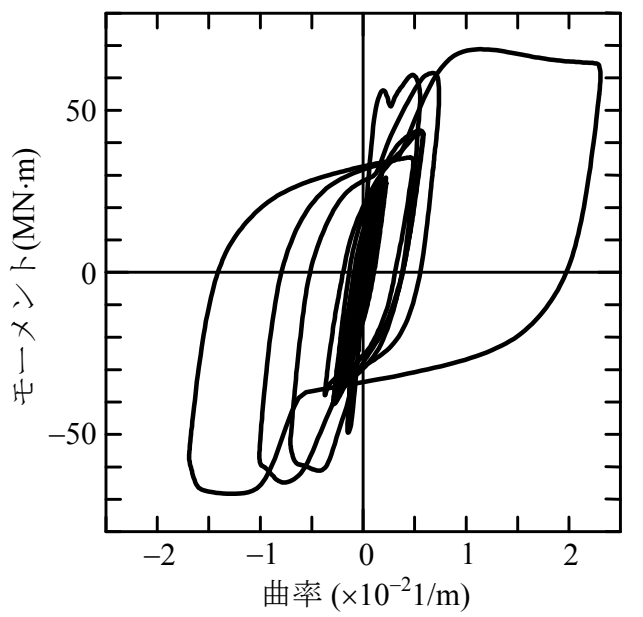

図-16 JR 鷹取駅記録に対する P1 橋脚基部のモーメント 一曲率の履歴 (橋軸方向)

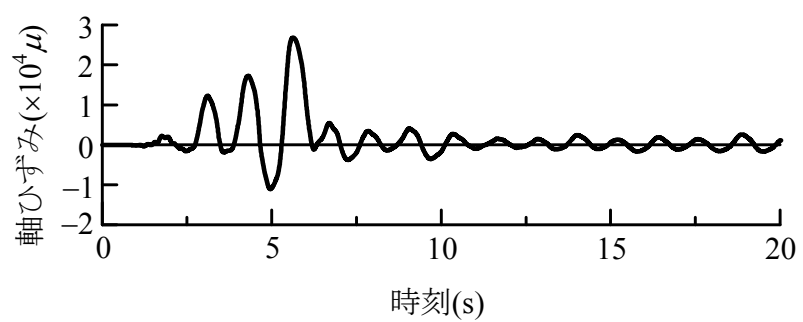

図-18 P1 橋脚の軸方向鉄筋ひずみの時刻歴 (JR 鷹取駅記録，橋軸方向最外縁軸方向鉄筋位置）

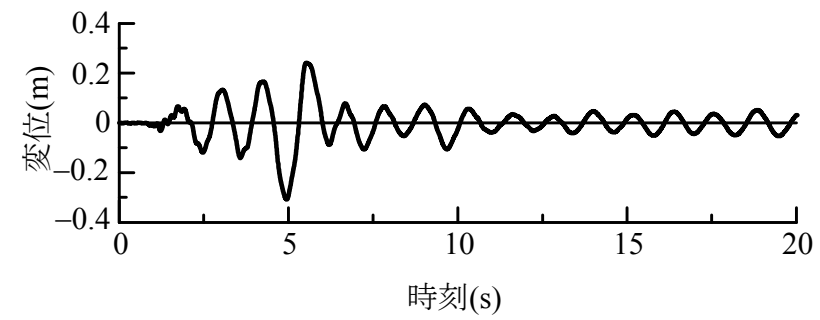

図-20 P1 橋脚上端の変位 (JR 鷹取駅記録，橋軸方向 $)$

討が必要不可欠である.

図-17 及び図-18 に，橋軸方向の最外縁軸方向鉄 筋位置における軸方向鉄筋のひずみの時刻歴を示 す。前記した曲げモーメントー曲率の履歴へ及ぼ 寸上下方向地震動の短周期成分の影響が小さかっ たことからも明らかなように, KiK-net 一関西記録 の高振動数成分の有無によってひずみの時刻歴に は曊著な相違は見られない. 図-19 及び図-20に, P1 橋脚上端における橋軸方向の変位を示す。ここ で，変位の正方向は，図-17 および図-18において, 正のひずみ, 寸なわち引張ひずみが生じる方向と なっている. 図-19 の橋脚上端の応答変位と対応す 


\section{— オリジナル地震動}

- - - ローパスフィルター $(3 \mathrm{~Hz})$ 処理地震動

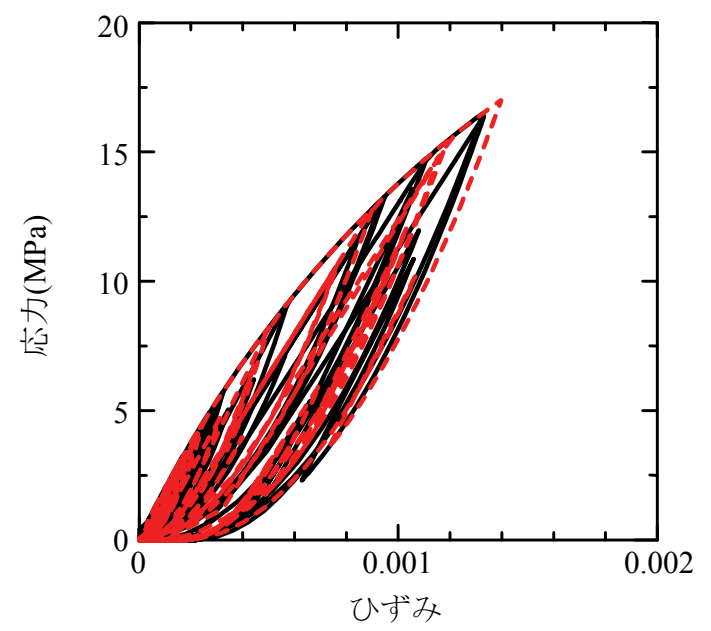

図-21 コアコンクリートの応力ーひずみ履歴 (KiK-net 一関西記録，橋軸方向最外縁軸方向鉄筋位置)

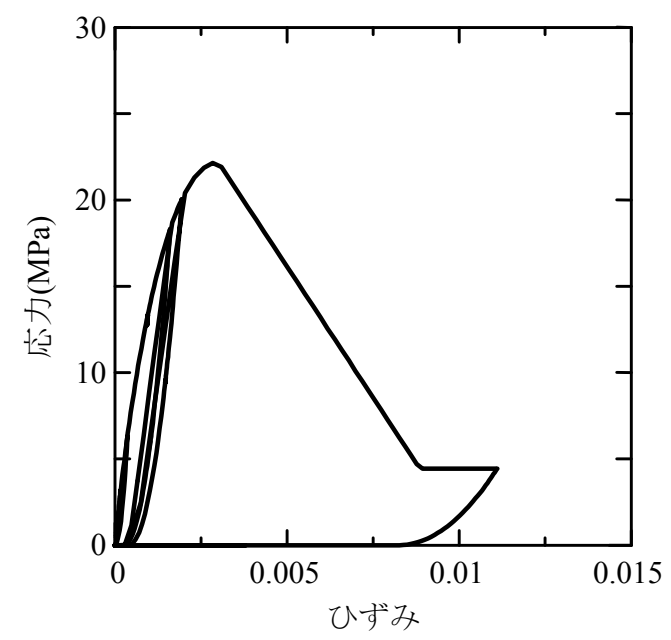

図-23 コアコンクリートの応力ーひずみ履歴 (JR 鷹取駅記録，橋軸方向最外縁軸方向鉄筋位置)

る図-17に示す軸方向鉄筋のひずみを比較してみる. $\mathrm{RC}$ 構造であることから, 当然, 圧縮側では軸方向 鉄筋のひずみは小さいため, 引張側のひずみに着 目し, これと橋脚の応答変位を比較すると, 両者 で最大值が生じる時刻をはじめ, 応答の時間的な 大小関係がよく一致している。これに対して, 図17 を軸力の時刻歴である図-13 と比較すると, 応 答の特徴はほとんど一致していない。このことは， 自重による圧縮軸力に匹敵する程の引張軸力が橋 脚に作用した場合であっても，その引張軸力によ って橋脚に生じる引張ひずみに比べて, 橋脚の曲 げ変形によって生じる引張ひずみの方が卓越する ことを示している。このような点から評価すると， 前記した短周期の軸力変動による曲げ耐力の変動 を除けば，短周期成分が卓越した最大加速度 $4 \mathrm{~g}$ に も及ぶ上下方向地震動が橋脚に生じるひずみに及 ぼす影響は小さいと言うことができる.

最後に, P1 橋脚におけるコアコンクリートの圧
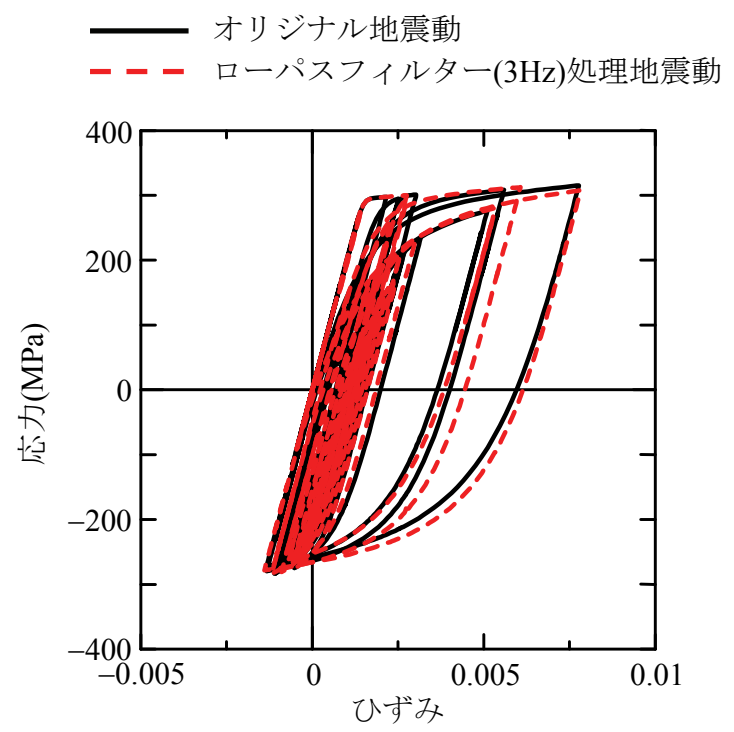

図-22 軸方向鉄筋の応力ーひずみ履歴

(KiK-net 一関西記録, 橋軸方向最外縁軸方向鉄筋)

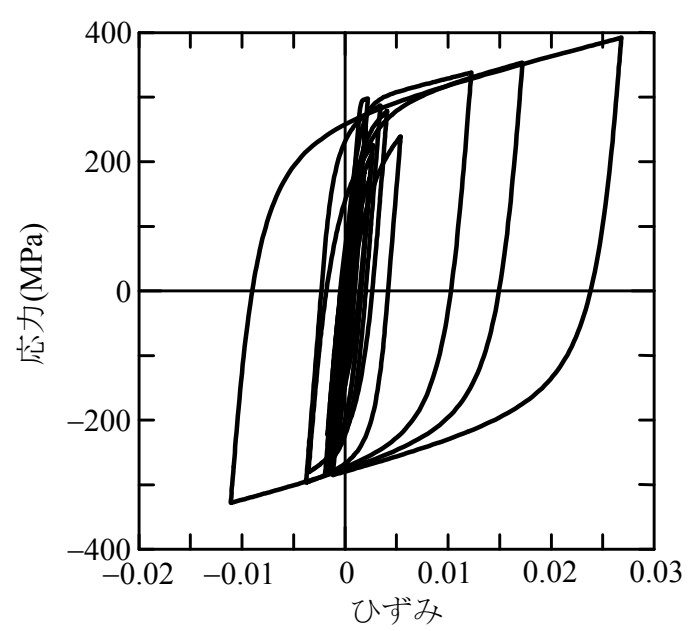

図-24 軸方向鉄筋の応力ーひずみ履歴 (JR 鷹取駅記録，橋軸方向最外縁軸方向鉄筋)

縮側の応力ーひずみ履歴，また同位置における軸 方向鉄筋の応力ーひずみ履歴について, KiK-net 一 関西記録，JR 鷹取駅記録のそれぞれについて，図21〜図-24 に示す.JR 鷹取駅記録を入力した場合 には, 設計上の終局を超える大きなひずみがコン クリートに生じている. 一方で, KiK-net 一関西記 録を入力した場合には，コンクリートの応力ーひ ずみ履歴は未だプレピーク域に収まっており，上 下方向地震動の短周期成分が応力ーひずみの履歴 に及ぼす影響は小さい。これは，前記したように， 引張を含む軸力変動によって生じるひずみよりも， 曲げ変形によるひずみが支配的だからである，従 って, KiK-net 一関西記録のオリジナル地震動を入 力した場合には引張軸力が生じるとは言え, 引張 ひずみの大きさは, JR 鷹取駅記録を作用させた場 合の 3 割程度に過ぎず，上下方向地震動の短周期 成分がコンクリートや鉄筋の応力ーひずみの履歴 に及ぼす影響は大きいものではない。 


\section{5. まとめ}

本研究では，2008年岩手・宮城内陸地震で観測 されたKiK-net一関西記録を用いて，短周期成分が 卓越した上下方向地震動が一般的な桁橋の地震応 答に及ぼす影響について, ファイバー解析により 検討した。本解析の結果, 明らかとなった事項は 以下の通りである.

1) 短周期成分が卓越した上下方向地震動が作用し た場合には，桁の上下方向応答を励起させ，自 重に匹敵する引張軸力を含む大きな軸力変動が 橋脚に生じる.

2) 本解析の条件では, 軸力変動が桁の応答変位や 橋脚の塑性ヒンジ部におけるモーメントー曲率 の履歴, コアコンクリートや軸方向鉄筋の応力 一ひずみの履歴に及ぼす影響は小さい.

謝辞：本研究を実施するに当たり，独立行政法人 防災科学技術研究所の基盤強震観測網KiK-netの観 測記録を使用させて頂きました。関係各位に感謝 申し上げます。

\section{参考文献}

1) 日本道路協会 : 道路橋示方書 - 同解説 $V$ 而震設計編, 2002.

2）菊池健児，吉村浩二，篠田広明：上下地震動が $\mathrm{RC}$ 造 有壁立体架構の動的弾性挙動に及ぼす影響, 第8回コ ンクリート工学年次講演会論文集, pp.737-740, 1986.
3) Papazoglou, A. J. and Elnashai, A. S.: Analytical and field evidence of the damaging effect of vertical earthquake ground motion, Earthquake Engineering and Structural Dynamics, Vol.25, No.10, pp.1109-1137, 1996.

4) Elnashai, A. S. and Papazoglou, J.: Procedure and spectra for analysis of RC Structures subjected to strong vertical earthquake loads, Journal of Earthquake Engineering, Vol.1, No.1, pp.121-155, 1997.

5) 日本道路協会：道路橋の耐震設計に関する資料, 1997.

6) Hoshikuma, J., Kawashima, K. and Taylor, A.W.: StressStrain Model for Confined Reinforced Concrete in Bridge Piers, Journal of Structural Engineering, ASCE, Vol.123, No.5, pp.624-633, 1997.

7) Sakai, J. and Kawashima, K.: Unloading and Reloading StressStrain Model for Confined Concrete, Journal of Structural Engineering, ASCE, Vol.132, No.1, pp.112-122, 2006.

8) 堺淳一, 川島一彦：部分的な除荷・再載荷を含む履 歴を表す修正Menegotto-Pintoモデルの提案, 土木学 会論文集, No.738/I-64, pp.159-169, 2003.

9) 小野新, 白井伸明, 安達洋, 坂槇義夫 : 変動軸力を 受ける鉄筋コンクリート柱の弾塑性性状, コンクリ 一ト工学年次論文報告集, Vol. 11, No. 2, pp. 495-500, 1989.

10) Abrams, D. P.: Influence of Axial Force Variations on Flexural Behavior of Reinforced Concrete Columns, ACI Structural Journal, pp. 246-254, 1987.

11）堺淳一, 川島一彦: 引張力を含む軸力変動がRC橋脚 の変形性能に及ぼす影響, 構造工学論文集, Vol.48A, pp.735-746, 2002.

（原稿受理2009年6月28日）

\section{EFFECT OF HIGH FREQUENCY COMPONENT PREDOMINANT VERTICAL GROUND MOTIONS ON THE SEISEMIC PERFORMANCE OF A BRIDGE}

\section{Hiroshi MATSUZAKI and Kazuhiko KAWASHIMA}

Nearfield ground motions recorded in recent years include high frequency components which make the PGA of the vertical components much higher than the PGA of the lateral components. The effect of high frequency component which was predominant in the vertical ground motion on the response of a standard bridge was studied. KiK-net Ichinoseki-nishi record during the 2008 Iwate-Miyagi Nairiku earthquake was imposed to the target bridge. It was found from the analysis that the high vertical acceleration can result in instantaneous tension in addition to high compression pulses in the bridge pier. 